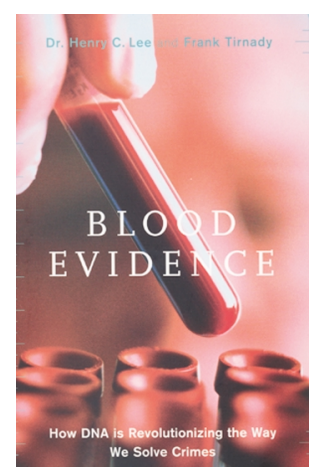

\section{Blood evidence: how DNA is revolutionizing the way we solve crimes}

\author{
by Henry C. Lee and Frank Tirnady \\ Basic Books. New York, New York, USA. 2003. \\ 448 pp. \$26.00. ISBN: 0-7382-0602-4.
}

Reviewed by Rony Duncan and Bob Williamson

E-mail:duncanr@murdoch.rch.unimelb.edu.au and

williamb@cryptic.rch.unimelb.edu.au

Many attempts are made to write books that are both erudite and exciting. Most fail, but from the first paragraph, Blood Evidence is an exception. Creating a book that reads more like a murder mystery than a scientific text, Henry Lee, an eminent American forensic pathologist, has teamed up with lawyer Frank Tirnady to describe case after case of nail-biting whodunits while demonstrating how such cases were transformed through DNA technology. The real beauty of this text is that, while telling tales of crime, conviction, and sometimes even exoneration, Lee and Tirnady simultaneously take us on a journey that illuminates scientific discovery - from what genes are to how PCR was developed to the method used to clone Dolly. Texts describing the science behind DNA technology can be dry, but Blood Evidence educates the reader about this science in such a subtle way that the reader hardly notices.

From the start, the book notes that of the 10,000 or so DNA tests requested in the US each year for forensic purposes, between 25 and $30 \%$ end up excluding the prime suspect. In other cases, a positive result is usually followed by a guilty plea. This underlines how valuable DNA fingerprinting testing has become to forensics - it can simultaneously protect the innocent and help in convicting the guilty.

The cases described by Lee and Tirnady are far ranging. Two chapters are devoted to the search for what they call the "world's most wanted man" Auschwitz camp doctor Josef Mengele.
The reader is educated on the origins of eugenic policy, the links that have existed between genetic research and human atrocity, and the development of the Nuremberg Code. Another two chapters are devoted to the recent case of Orenthal James (O.J.) Simpson. The reader is privy to a detailed description of the evidence that was presented by the prosecution in an attempt to demonstrate that Simpson was guilty beyond reasonable doubt of killing his ex-wife Nicole Brown Simpson and her friend Ronald Goldman. The reader learns of the stringency required of police in order for DNA evidence to hold up in court. The authors also provide some insight into this ultimate "not guilty" verdict but do not, unfortunately but understandably, discuss in detail the fact that historical racism by the Los Angeles police would lead a jury to give at least some credibility to any trial claim that evidence was planted.

Other stories used to showcase the wide variety of uses for DNA technology include those of tracing the lineage of the ancient woolly mammoth with a 40,000-year-old sample and the conviction of Kenneth R. Nelson in Wyoming of illegal antelope hunting. Tales of the marital indiscretions of President Bill Clinton are explored. There are even descriptions of the ways in which bear DNA helps rangers to catch "habituated" bears who have lost their fear of humans and may become dangerous to people in camping grounds.

In addition to these rather colorful stories, Blood Evidence also flags some of the more controversial uses of DNA technology, such as cloning, genetic engineering, and stem cell use. Although the discussions surrounding these topics are far from detailed, Lee and Tirnady do draw attention to the ethical issues involved and explain the science behind the controversies.

The science in Blood Evidence is treated in such a way that even experienced geneticists will find the material illuminating reading. For example, although many readers will know of the power of the gene amplification technique known as polymerase chain reaction (PCR), only very few may know about the racy way Kary Mullis pieced the process together along a mountainous highway in California. The book also describes the progress of PCR from an idea to a laboratory process, and how difficult it was for Mullis and his colleagues to gain acceptance of its specificity and robustness in the context of police forensics. Those less familiar with the science of genetics are not left behind, while those more an fait with genetics are not bored.

The book looks to the future, discussing the coming world of "real-time DNA fingerprinting," where a DNA chip at the scene of a crime will be able to provide data to investigators within a matter of minutes through the use of a hand-held device. It is a pity that the proposal that everyone should be DNA fingerprinted (in the same way that every baby in the United States has its "real" fingerprints taken at birth) is not discussed. Nor are the fairly tough US laws making it difficult to use evidence in criminal trials if the evidence has been collected improperly. These are relevant issues for the future since, as the authors note, DNA evidence is now almost always accepted as conclusive in criminal cases.

Blood Evidence is not a text that readers can use as a reference, for the topics are interwoven throughout the chapters and not clearly designated. This style makes for a wonderful novel, and that is exactly how we wish to recommend this text. Read it from cover to cover as a great story. Let the science and its implications just sink in around the terrific tales that are told. 